\title{
Modelling of Irrigation Return Flow in Unconfined Aquifer of Dharoi Command in Mehsana District of Gujarat, India
}

\author{
Hema R. Parmar, Pradeep Majumdar
}

\begin{abstract}
Abstact: Surface water flow and subsurface flow have traditionally been investigated separately and simulators have been developed over the years, to model each of these systems. Growing interest in conjunctive water management, and need for simulations of surface/subsurface flow and their interactions has lead to the linking of models of the respective domains. This study from Dharoi command area, using MODFLOW, showed pertaining to the second layer of the calibrated model. The first layer is a thin soil cover layer of about $\mathbf{3}$ m uniform thickness. Top layer is kept under unconfined water table condition, where as the next layer is given the scope of transforming between water table to confined state and vice versa depending upon the fluctuation of the computed water level with respect to the bottom boundary of the top layer. No recharge and discharge options other than a single boundary condition of average May water level in the extreme north-east grid has been allowed. This calibration is based upon matching the observed and computed average gradient of the water table (hydraulic gradient) and nothing to do with matching the point to point values of the observation wells as that could lead to misappropriation in respect of hydrologic condition. Over all gradient of the water table in the area of interest is computed as $0.23 \mathrm{~m}$ per $\mathrm{km}$ in comparison to an observed hydraulic gradient of $0.3 \mathrm{~m}$ per $\mathrm{km}$. The rivers such as Sabarmati downstream of Dharoi dam and up to Bijapur, Rupen and Pushpawati are activated in the transient run. Conductance value is considered as $0.0001 \mathrm{~m} / \mathrm{sec}$ for all the rivers. proximity of the second layer under unconfined state. Comparisons of water levels in selected locations. Overall match between the trends and the point values indicate that the calibrated model transient run can be considered as base case and various options can be studied with this model. Visual MODFLOW is very effective to know the present scenario of ground water flow, water level of aquifer, wells, also point values indicate that the calibrated model transient run can be considered as base case and various options can be studied with this model. Visual MODFLOW is very effective to know the present scenario of ground water flow, water level of aquifer, wells, also distribution of spatial recharge, specific yield distribution. It gives very close result to the observed value.
\end{abstract} Key words: Aquifer, Irrigation return flow, MODFLOW, Specific yield

Manuscript received on October 08, 2021.

Revised Manuscript received on October 22, 2021.

Manuscript published on October 30, 2021.

* Correspondence Author

Hema R. Parmar*, Ph.D Student from Charusat University, Changa. E mail-hemavanar@gmail.com

Dr. Pradeep Majumdar, Professor, Department of Civil Engineering, CU Shah University, Gujarat, patmajum@yahoo.com

(C) The Authors. Published by Blue Eyes Intelligence Engineering and Sciences Publication (BEIESP). This is an open access article under the CC BY-NC-ND license (http://creativecommons.org/licenses/by-nc-nd/4.0/)

\section{INTRODUCTION}

\subsection{Impact of Irrigation:}

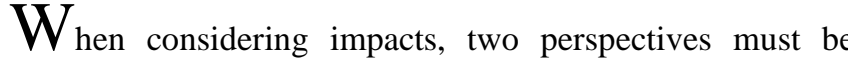
taken into account, those of: the project on the environment, and external factors on the project (externalities). In the detailed sections below, many of the impacts described are most extreme in the case of new irrigated areas. However, rehabilitation and changes resulting from alterations to the operating infrastructure, for example, will also have environmental impacts that may not at first be anticipated. The intensification of agriculture can lead to groundwater pollution related to the increased use of pesticides and fertilizers. Improved efficiency may significantly reduce return flows which are often utilized downstream by other irrigation schemes or wildlife habitats. Similarly, upstream developments are likely to impact on an irrigation scheme either in the form of reduced water availability (surface or groundwater) or reduced water quality. Different types of irrigation will have different impacts and it should not be assumed that modern methods will have fewer impacts: they may significantly increase energy consumption and lead to social problems due to reduced employment in agriculture. Impacts will also vary according to the stage of implementation. For example, during the construction period there may be specific health and other social risks due to an influx of migrant workers living in temporary and unsanitary accommodation. Later, once the project has been operating for several years, cumulative impacts may begin to present serious environmental constraints to project sustainability. Such issues must be predicted by the EIA and mitigation measures prepared. The most common problems of, Degradation of irrigated land, Salinization, Water logging, Poor water quality etc and threats to, irrigation schemes are Degradation of irrigated land.The sections below describe the most common environmental impacts associated with irrigation schemes. Under each item, both positive and negative impacts are briefly described and the most usual mitigating measures outlined. The opportunity to identify positive impacts and to propose measures to enhance such impacts should not be neglected. Changes to the low flow regime may have significant negative impacts on downstream users, whether they abstract water (irrigation schemes, drinking supplies) or use the river for transportation or hydropower.

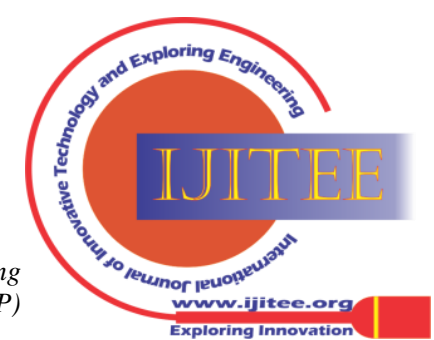


Minimum demands from both existing and potential future users need to be clearly identified and assessed in relation to current and future low flows. The quality of low flows is also important. Return flows are likely to have significant quantities of pollutants. Low flows need to be high enough to ensure sufficient dilution of pollutants discharged from irrigation schemes and other sources such as industry and urban areas. A reduction in the natural river flow together with a discharge of lower quality drainage water can have severe negative impacts on downstream users, including irrigation schemes.

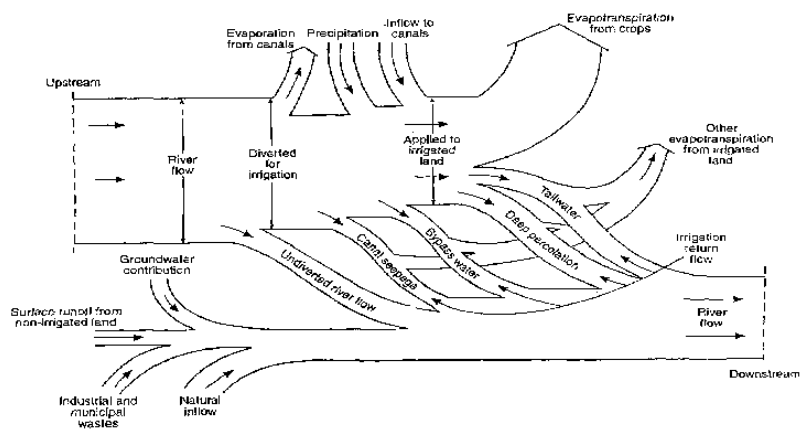

Fig. 1 Conceptual diagram of the irrigation return flow system for a given reach of a river system

In the present paper groundwater flow model MODFLOW is applied to a command area irrigated by the canal systems of the storage reservoir created by constructing Dharoi Dam on the Sabarmati River. Vertical and horizontal heterogeneities are included in the model geometry and groundwater flow in the unconfined aquifer to an average depth of $20 \mathrm{~m}$ is conceptualised, calibrated and put forward.

\section{STUDY AREA}

\section{A. Location:}

The study area falling under latitude $20^{\circ} 00^{\prime \prime}$ and $24^{\circ} 42^{\prime}$ " north and longitude $68^{\circ} 08^{\prime \prime}$ and $74^{\circ} 48^{\prime \prime}$ east is located in Mehsana district of Gujarat state covering parts of Mehsana, agricultural command area under dense canal network is more or less plain topography on an elevation of $92.96 \mathrm{~m}$ above sea level with occasional local hill tops. Surface level contours are shown in Figure. 2. Major drainages are Pushpawati River and Rupen River; flows are evident only during intense rainfall. Two river cross sections each for Pushpawati and Rupen are shown in Figure. 3.

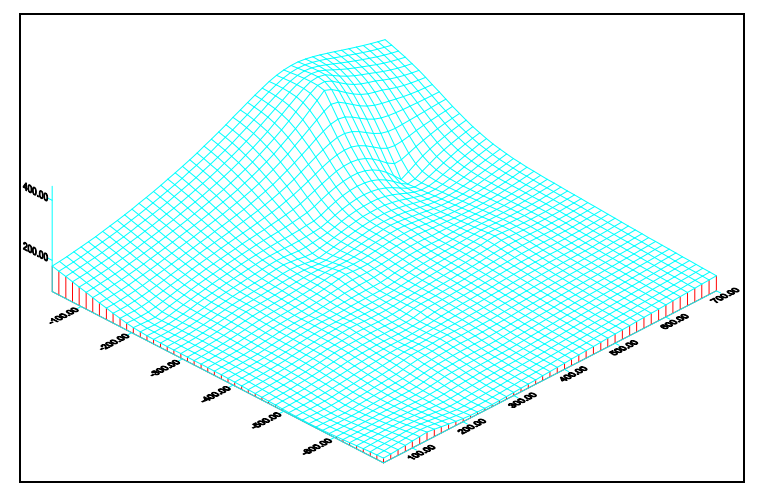

Fig. 2: Surface level contours depicting the topography of the area Visnagar, Vadnagar, Kheralu and Unjha taluks. An

\section{B. Rainfall:}

South-West monsoon is effective in North-Gujarat region. Major precipitation is being received between June to September. July is the wettest month of monsoon season. Rainfall pattern is found erratic in the region. Nearly 40 days of rainfall are recorded in most of the areas of NorthGujarat region.

\section{Raw Data Analysis and Model Conceptualisation}

\section{Model Area:}

A water table aquifer area of $65.7 \mathrm{~km} \mathrm{X} 65.4 \mathrm{~km}$ is considered for groundwater flow modelling. The area is selected so as to encompass the Dharoi dam and its agricultural command irrigated by the right bank canal system comprised of main canal, extended main canal, 5 branch canals, distributaries and minors. Observation well locations shown in Figure. 4 indicate that information is suitably available for an area surrounded by right bank canal in north, Vadnagar branch canal on east, Pushpawati River in west and command boundary on the southern side. Therefore analysis is concentrated on such area having better data availability, rest of the model area is included for future expansion and keeping the model results free from boundary effects. The conceptual model covers mainly the information about Visnagar and Vadnagar regions; hence present paper would spell much about these regions.

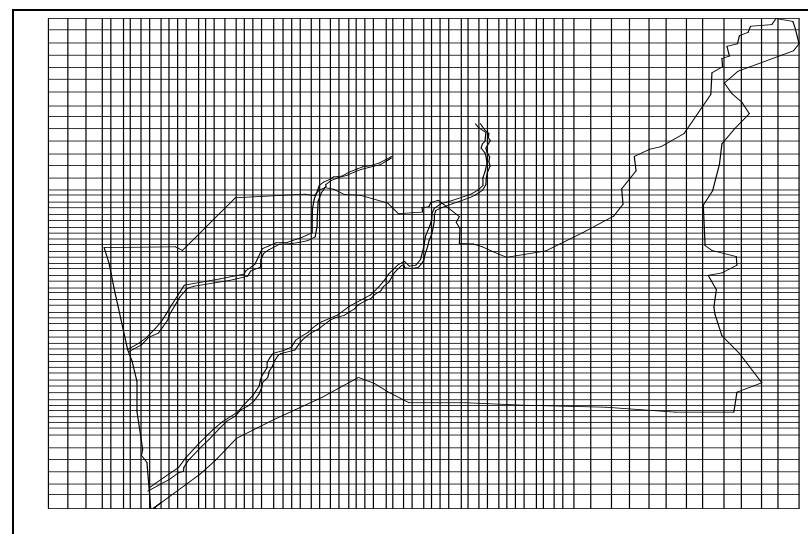

Fig. 3 Descretisation of study area

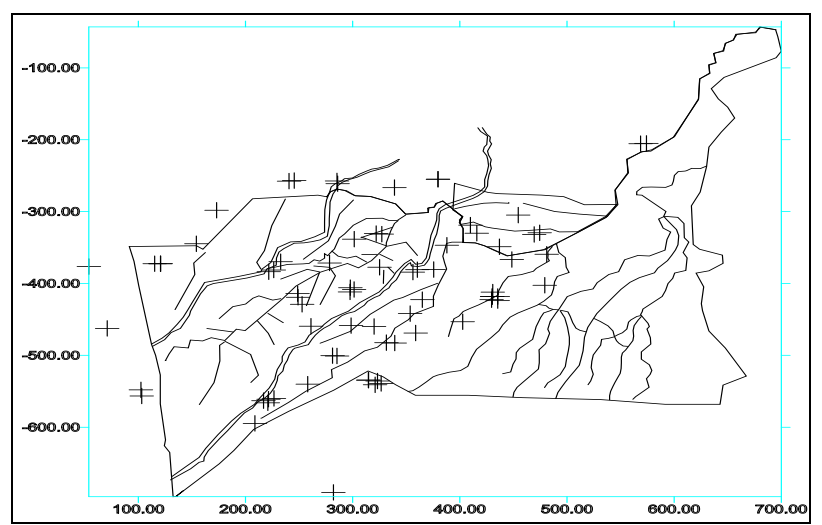

Fig 4 Model Area co-ordinated between $(43,-697)$ to $(700,-43)$

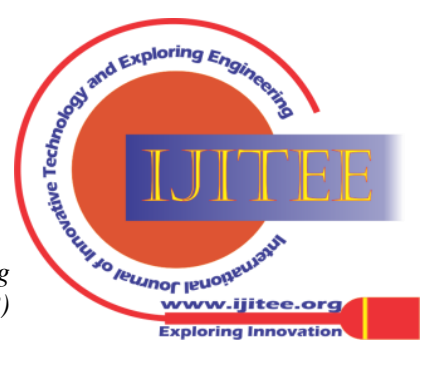


The finite difference grids are discredited in the model area. The grid sizes in the central region are finer and of the order of $516 \mathrm{~m} \mathrm{X} 516 \mathrm{~m}$, where as in other regions grid size is kept as coarser as $1.7 \mathrm{~km} \mathrm{X} 1.7 \mathrm{~km}$. Non uniform grid generation is intended at concentrating on the central region having better data input. Whereas rest of the area can be improved as and when adequate data is available in those regions. The grids can still be finer in the central region as well, however that is not felt necessary at this stage looking at the objective of dealing with regional groundwater flow. It helps in controlling the computer memory that is required for executing model runs fast and smooth

Table 1 well details of study area

\begin{tabular}{|c|c|c|c|c|c|c|c|}
\hline Sr. No. & Village & Well type & $\begin{array}{l}\text { Dia of well } \\
\text { in } \mathbf{m}\end{array}$ & Depth & SWL in $\mathbf{m}$ & Drawdown in $\mathrm{m}$ & $\begin{array}{c}\text { Discharge in } \\
\text { LPM }\end{array}$ \\
\hline 1 & Malekpur & Dug & 2.7 & 14.2 & 4.4 & 4 & 400 \\
\hline 2 & Malekpur & Dug & 3.3 & 10.1 & 2.15 & 2 & 300 \\
\hline 3 & Malekpur & DCB & 2.8 & 14.2 & 1.8 & 1.5 & 400 \\
\hline 4 & Bajpur & DCB & 2.4 & 19.5 & 17.9 & 6 & 250 \\
\hline 5 & Vadnagar & DCB & 3.55 & 18.9 & 13.6 & & 400 \\
\hline 6 & Malekpur & DCB & 3.05 & 21.15 & 4.85 & & 400 \\
\hline 7 & Vadnagar & DCB & 2.8 & 18.4 & 10 & 6 & 400 \\
\hline 8 & Denap & DCB & 2.8 & 13.5 & 4 & 5 & 500 \\
\hline 9 & Denap & DCB & 3 & 26 & 11.5 & 8 & 600 \\
\hline 10 & Malekpur & DCB & 2.8 & 18.2 & 2.1 & & 0 \\
\hline 11 & Sultanpur & DCB & 3.1 & 30.1 & 6.1 & & 0 \\
\hline 12 & Navapura & DCB & 4 & 10.5 & 6 & 4 & 400 \\
\hline 13 & Navapura & Dug & 4.1 & 13 & 5 & 6 & 400 \\
\hline 14 & Navapura & DCB & 3.3 & 11.5 & 4 & 6 & 400 \\
\hline 15 & Champa & Dug & 4.5 & 12.2 & 3.3 & & \\
\hline 16 & Champa & DCB & 3.6 & 11.6 & 6 & 5 & 400 \\
\hline 17 & Champa & DCB & 4 & 11.2 & 3.5 & & 400 \\
\hline 18 & Kamalpur & DCB & 3.2 & 18.1 & 4.9 & 10 & 400 \\
\hline 19 & molipur & DCB & 4.2 & 15.25 & 3.3 & 6 & 500 \\
\hline 20 & molipur & DCB & 4.2 & 17 & 11.3 & 6 & 400 \\
\hline 21 & molipur & DCB & 3.3 & 12.6 & 3.1 & 6 & 400 \\
\hline 22 & molipur & DCB & 4.2 & 14.3 & 4.55 & 6 & 400 \\
\hline 23 & sulipur & DCB & 3.2 & 15.45 & 8.8 & 6 & 400 \\
\hline 24 & sulipur & DCB & 2.8 & 14.8 & 9.5 & 6 & 450 \\
\hline 25 & sulipur & DCB & 3.3 & 14.2 & 4.4 & 6 & 450 \\
\hline 26 & Badarpur & DCB & 3.8 & 9.8 & 4.4 & 4.5 & 500 \\
\hline 27 & Badarpur & DCB & 4.8 & 12.4 & 5.2 & 6 & 600 \\
\hline 28 & Badarpur & DCB & 5.5 & 9.3 & 4.85 & 4 & 600 \\
\hline 29 & Badarpur & DCB & 3.6 & 11.5 & 5.4 & 5 & 500 \\
\hline 30 & Champa & DCB & 3.8 & 15.5 & 8 & 6 & 400 \\
\hline 31 & Umta & Dug & 2.3 & 14 & 3 & 3 & 400 \\
\hline 32 & Umta & Dug & 3.2 & 19.2 & 8 & 6 & 400 \\
\hline 33 & Umta & DCB & 2.8 & 25.6 & 14 & 6 & 600 \\
\hline 34 & Umta & DCB & 2.2 & 13.2 & 5.6 & 6 & 400 \\
\hline 35 & denap & DCB & 2.6 & 19.65 & 5.6 & 6 & 425 \\
\hline 36 & Umta & DCB & 4.2 & 13 & 6 & 6 & 600 \\
\hline 37 & Sarna & DCB & 6 & 23 & 7.6 & 12 & 500 \\
\hline 38 & Sarna & DCB & 6.8 & 9.6 & 6.5 & 3 & 800 \\
\hline 39 & Sarna & DCB & 3.8 & 16.8 & 6 & 9 & 500 \\
\hline 40 & Memedpur & DCB & 2.4 & 16.6 & 15.7 & not measurable & 300 \\
\hline
\end{tabular}


Modelling of Irrigation Return Flow in Unconfined Aquifer of Dharoi Command in Mehsana District of Gujarat, India

\begin{tabular}{|l|c|c|c|c|c|c|c|}
\hline 41 & Memedpur & DCB & 2.6 & 17.7 & 16.4 & not measurable & 400 \\
\hline 42 & Memedpur & DCB & 2.3 & 8.9 & 4.8 & 3 & 300 \\
\hline 43 & Rajgaddh & DCB & 2.9 & 18.9 & 24 in bore & not measurable & 300 \\
\hline 44 & Chandpur & DCB & 2.6 & 11.3 & 5.1 & 6 & 400 \\
\hline 45 & Chandpur & DCB & 2.7 & 8.8 & 4.8 & 6 & 400 \\
\hline 46 & Chandpur & Dug & 3.2 & 12.3 & 4.6 & 6 & 400 \\
\hline 47 & Rangpur & DCB & 3.75 & 21.5 & 14.2 & 6 & 350 \\
\hline 48 & Rangpur & DCB & 3.3 & 14.3 & 6.3 & 6 & 400 \\
\hline 49 & Rangpur & DCB & 2.9 & 16.6 & 6.9 & 6 & 450 \\
\hline 50 & Rangpur & DCB & 3 & 17 & 5.6 & 3 & 500 \\
\hline
\end{tabular}

Geo-referencing of the model area is based upon the command area map having scales in row and column directions in the ratio of 1:2. Based upon ground level data at around 50 locations in the model area, surface level contours are generated and shown in Figure.5. In general a

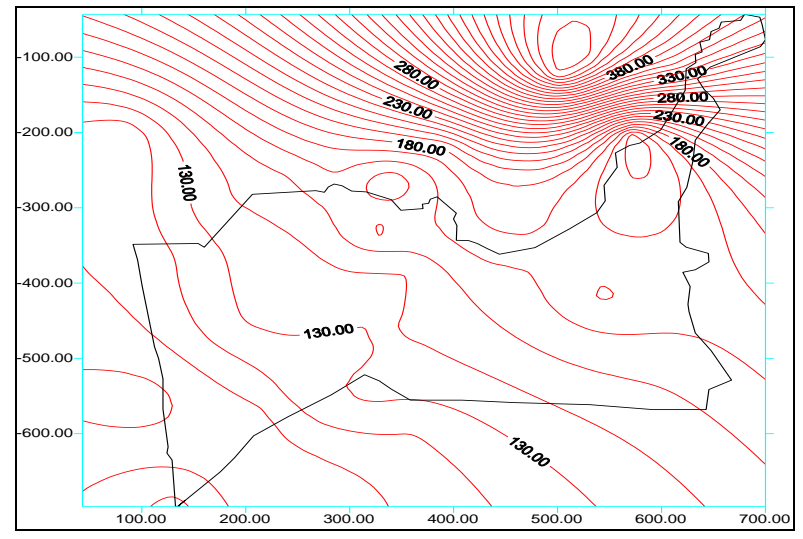

Fig 5 Surface level contours in the study area

Using 8 dug well logs and 15 bore logs two layered water table aquifer has been conceptualised. Surface level topography shown in Figure. 5, remains the top of the first aquifer and bottom layer contours of the aquifer is shown in Figure.8. Similarly bottom layer contours of the second aquifer are drawn in Figure. 9, as bottom of the first aquifer coincides with the top of the second aquifer. Grid levels of the contour plots are the input for the vertical heterogeneity of the model geometry. When developed in the Visual MODFLOW, typical two cross-sections, each of them rowwise from $(30,-610)$ and column-wise from $(-860,110)$ are included as Figur.6 and Figure.7 respectively. First layer is having a uniform soil thickness of $3 \mathrm{~m}$ and second layer exhibits varying thickness of around $5 \mathrm{~m}$ in north-east to 20 $\mathrm{m}$ in the south west, $100 \mathrm{~km}$ apart

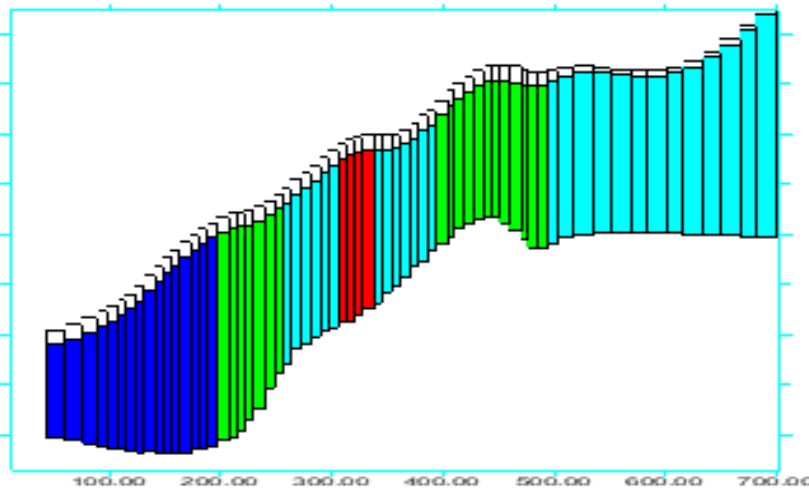

Fig 6 Row-wise model layers in the study area gentle slope is available from north-east to south-west direction. Both the existing rivers Pushpawati and Rupen also follow the same course of drainage pattern. Hence all the surface water flows including those in the canal systems follow the course from north-east to south west

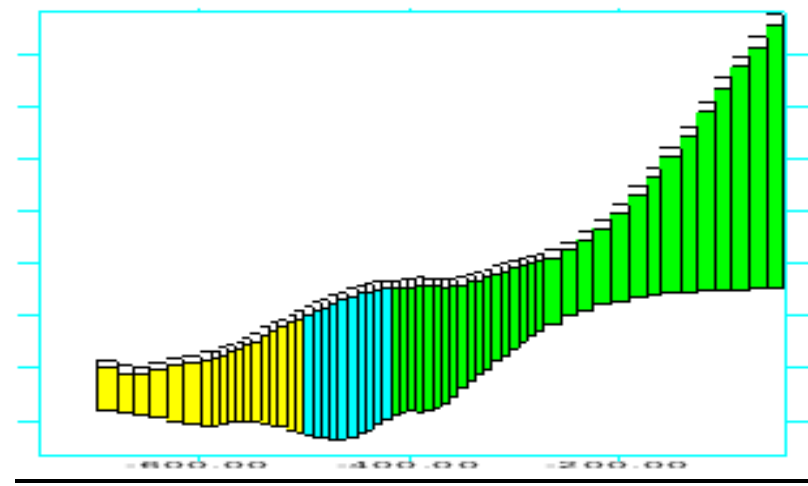

Fig 7 Column-wise model layers in the study area

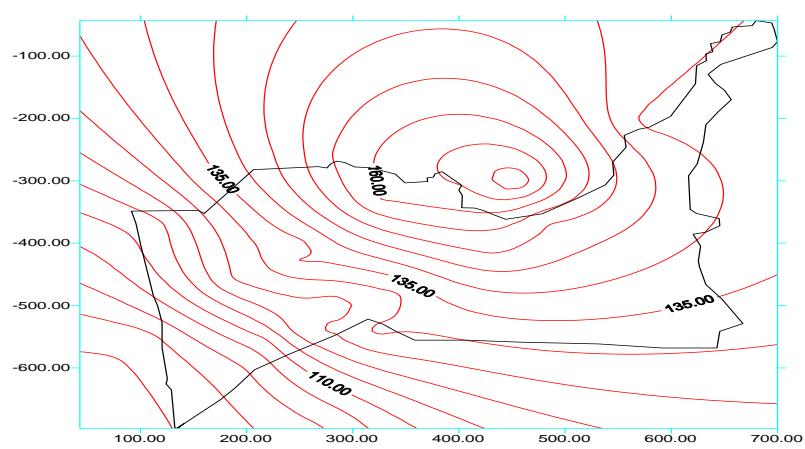

Fig. 8 First layer bottom level contours in the study area

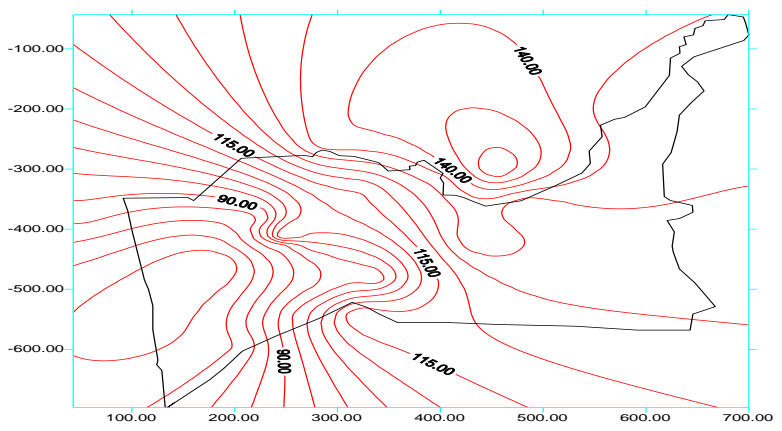

Fig 9 Second layer bottom level contours in the study area

Published By:

Blue Eyes Intelligence Engineering and Sciences Publication (BEIESP)

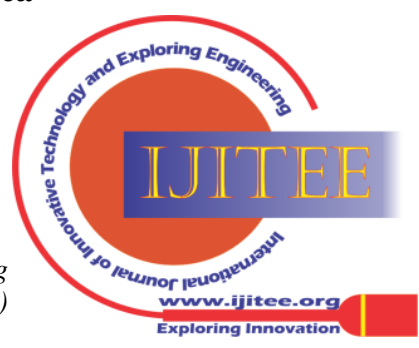


Horizontal heterogeneity pattern is produced in the second layer based upon the available aquifer parameter data at 24 locations of the model area. Iso-lines representing distribution of hydraulic conductivity and specific yield are presented vide Figure. 10 and Figure. 11 respectively. First layer is conceptualised to have homogeneous aquifer parameters of top soil. The aquifer parameter distributions in the second layer in Visual MODFLOW extension are developed using distributions of Figures.12 and 13.Hydraulic Conductivity distribution in the second layer of the model area are Red - 8.0, Yellow - 7.05, Green 16.6, Dark blue -4.04 and Specific Yield distribution in the second layer of the model area are Red -0.004 , Yellow 0.01077 , Green -0.004 , Blue -0.00181

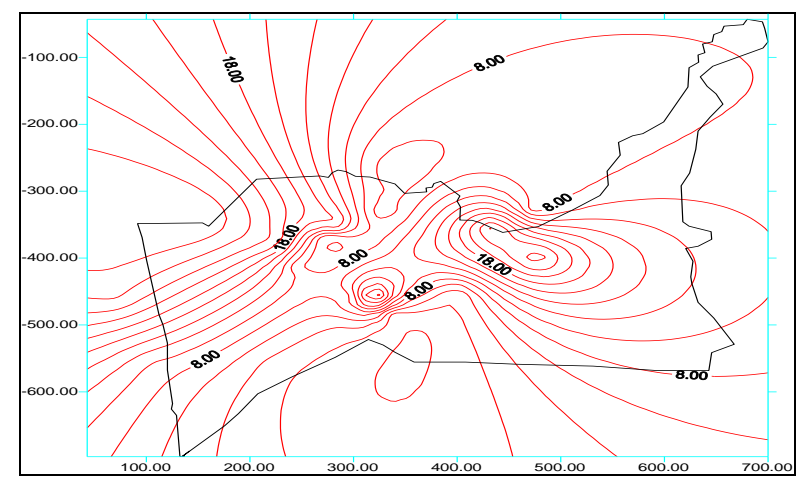

Fig 10 Hydraulic Conductivity distributions in second layer of study area

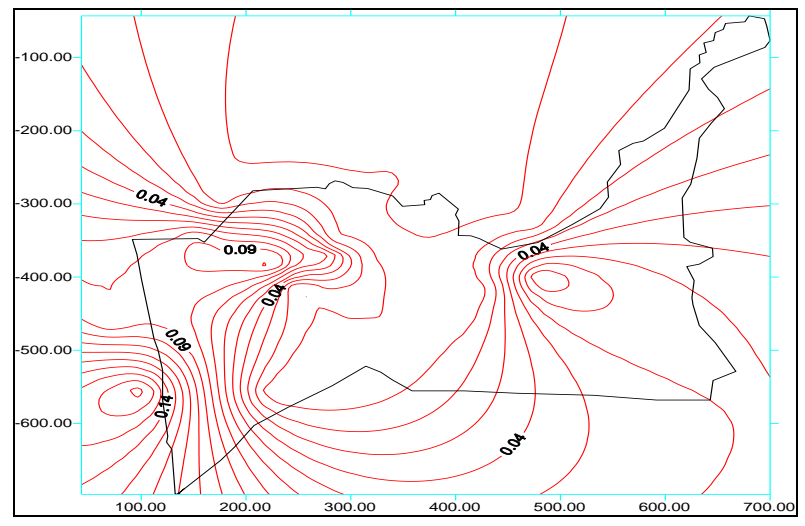

Fig. 11 Specific yield distribution in the second layer of study area

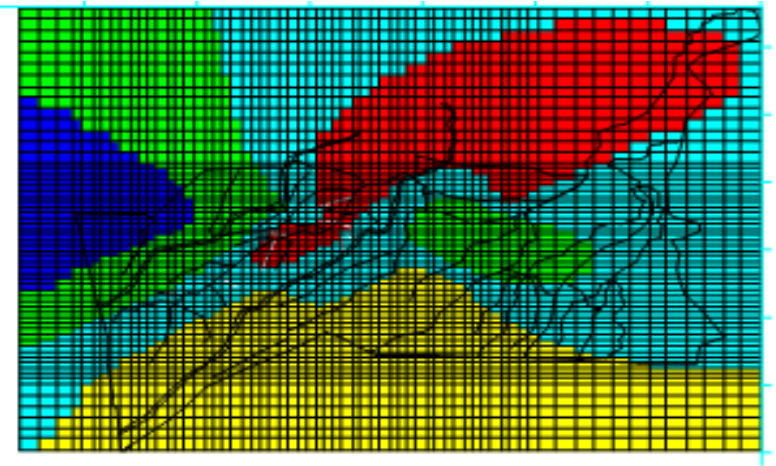

Fig 12 Hydraulic Conductivity distribution in the study area

\section{Model Parameters}

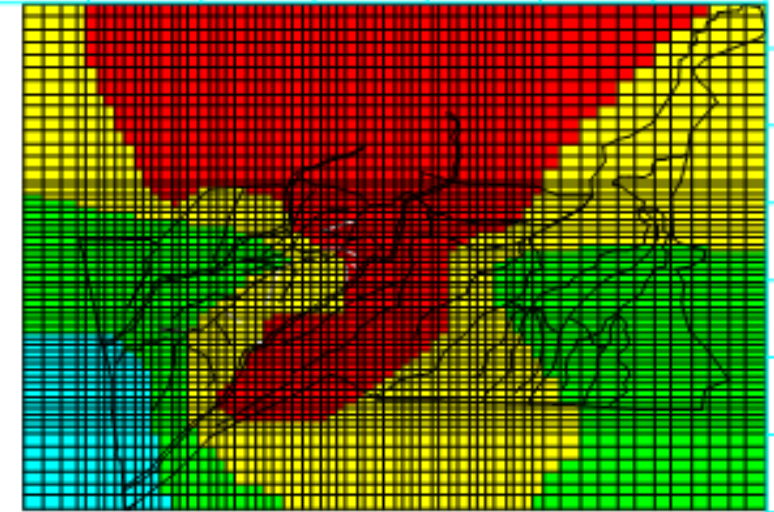

\section{Fig 13 Specific Yield distribution in the second layer of study area}

\section{Boundary Conditions}

Model area is not provided with any inactive blocks, which makes the water table aquifer infinite extent in regard to central region. The self imposed boundaries are the model extents in four sides. The central region of the model, which is the theme area of analyses, is quite away and presumed to have no effect of the model boundaries. Inside the domain of interest natural boundaries such as Pushpawati and Rupen rivers may have influence; however both are reported as dry in recent times, in most part of the year. No flows in these two rivers are actually the indicator of the water table condition of the region. Philosophically it is interesting to find the water table condition with some flow in these rivers and such exercise will follow its trial on the calibrated model in later part of this thesis. Regional flow pattern in the shallow water table aquifer is also suspected to be effected by the flow regimes of Sabarmati River downstream of Dharoi Dam. Absence of environmental flow in the river may have affected the groundwater condition. Temporal domain for the modelling exercise is individual monsoon season generally comprised of four months viz. June, July, August and September. With south-west monsoon effective, May conditions are the initial pre monsoon condition and October is said to be post monsoon scenarios. Recharge to the study domain is through rainfall in monsoon months and due to irrigation return flow and canal seepage in other months. There may be overlapping months where all the above sources participate in the recharge process. Monthly rainfall values in three seasons are around $15 \%$ of the rainfall is considered as recharge to groundwater table. Table 6.2 shows computed delta values based upon the monthly irrigation release for right bank canal command area of 45548 hectares. Irrigation return flow is considered as $40 \%$ of the month. Although most of the canal in the region is lined, however any seepage loss due to cracks in the canal network is taken care of in the $40 \%$ irrigation return flows. If required, RBC system can be augmented in the model area and effects of canal seepage can be reported as and when monthly flow data of various main, branches, distributaries and minor canals are available.

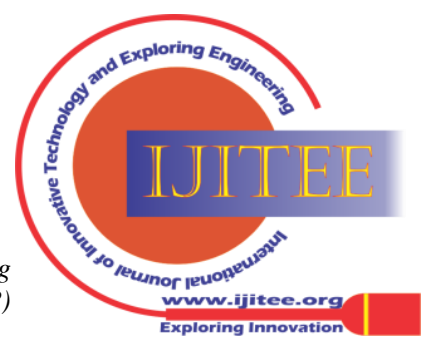


In absence of those details, the present application is fruitful. Bottom of the second layer is kept as impervious boundary. Although literature review shows possibility of vertical flow in the conceptual model, however it is presumed to play some role within individual layer and any interaction between the adjoining layers may be a subject of future research.

\section{E. Observed Water Table Condition}

Based upon 13 observation dug wells, contour plots are prepared. Static water level trends are plotted in Fig. 14 using the data for the month of May in the year 2000, 2003, 2006 and 2008. The trends are more or less similar in each year and follow the topography of the area shown in the surface level contours in Figure.5. During steady state calibration of the model the computed water table trends would be brought closer to static water level trends generated in Figure 14. Pre and post monsoon water levels for the year 2008 are plotted in Figure. 15. In post monsoon water levels, effect of drainages is clearly evident, indicating presence of stream aquifer interactions. Dharoi Dam water levels are plotted with groundwater levels in above three locations in Figure. 16. There is overall water table rise due to storage reservoir and effects are more significant in Vadnagar as compared to Visnagar and Denap because of its comparative vicinity. Water table of the region is clearly nfluenced by the water level in the reservoir, which can be termed as steady state condition of the region. Unsteady transformation of the water table is due to seasonal rainfall, canal release, and irrigation return flow and groundwater draft. Figure. 17 establishes the impact of rainfall and irrigation return flow. Conceptual model will take these parameters in to the consideration. Two spatial distributions concerning overall recharge and discharge are plotted in Figures. 18 and 19. These distributions are input to the calibrated model.

\section{F. Model Runs}

Geometry of the conceptual model is processed for calibration run with Initial aquifer parameters in Table 6.2 following the spatial distribution for second layer according to Figure 10. First layer is considered to have homogeneous soil property. Second layer values are the average of the limiting values of the particular zone. This run being under steady state, specific yield has no significance. The boundary condition, which becomes input at this stage, is the Dharoi dam reservoir level during May. Initial water table is kept at highest boundary value available in the region. Aquifer parameters are changed through trial and error to produce a general water table condition as depicted in Figure. 14.

Table - 6.2 Initial Aquifer Parameters for the Calibration run

\begin{tabular}{|c|c|c|c|c|c|c|c|}
\hline \multirow{2}{*}{ Sr No } & \multicolumn{2}{|c|}{ AQUIFER ZONE } & \multirow{2}{*}{$\begin{array}{l}\text { Kxx in m per } \\
\text { second }\end{array}$} & \multirow{2}{*}{$\begin{array}{l}\text { Kyy in m per } \\
\text { second }\end{array}$} & \multirow{2}{*}{$\begin{array}{l}\text { Kzz in m per } \\
\text { second }\end{array}$} & \multirow{2}{*}{$\begin{array}{c}\text { Porosity in } \\
\%\end{array}$} & \multirow{2}{*}{ Remarks } \\
\hline & Layer & Zone No & & & & & \\
\hline 1 & First & 1 & $1.0 \mathrm{e}-4$ & $1.0 \mathrm{e}-4$ & 1.0 e-5 & 0.35 & White \\
\hline 2 & Second & 2 & 1.0 e-5 & 1.0 e-5 & 1.0 e- 6 & 0.35 & Blue \\
\hline 3 & Second & 3 & 5.0 e- 6 & 5.0 e- 6 & 5.0 e-7 & 0.35 & Green \\
\hline 4 & Second & 4 & 0.00025 & 0.00025 & 0.000025 & 0.35 & Gray \\
\hline 5 & Second & 5 & 0.00015 & 0.00015 & 0.000015 & 0.35 & Red \\
\hline 6 & Second & 6 & 0.00004 & 0.00004 & 0.000004 & 0.35 & Pink \\
\hline
\end{tabular}

Once the model is calibrated under steady state condition, monthly transient runs are executed for a single season of 2006. Recharge and draft distributions of Figures. 18 and 19 are input for the calibration run. Average monthly draft values are taken as $14 \%$ Rivers such as Pushpawati and Rupen are activated for the transient runs. Initial water table conditions are the pre monsoon water table contours in Figure. 20. Post monsoon water level contours of the year 2006 in the Figure. 21 are matched with the computed water levels of this run. Specific Yield distribution of Figure 13 is the input for transient run other than the parameters calibrated through steady state run earlier. On this base case scenario of 2006, various trails are augmented to check the effect of irrigation return flow and water levels in the rivers like Rupen and Pushpawati. Results are discussed in the following chapter.

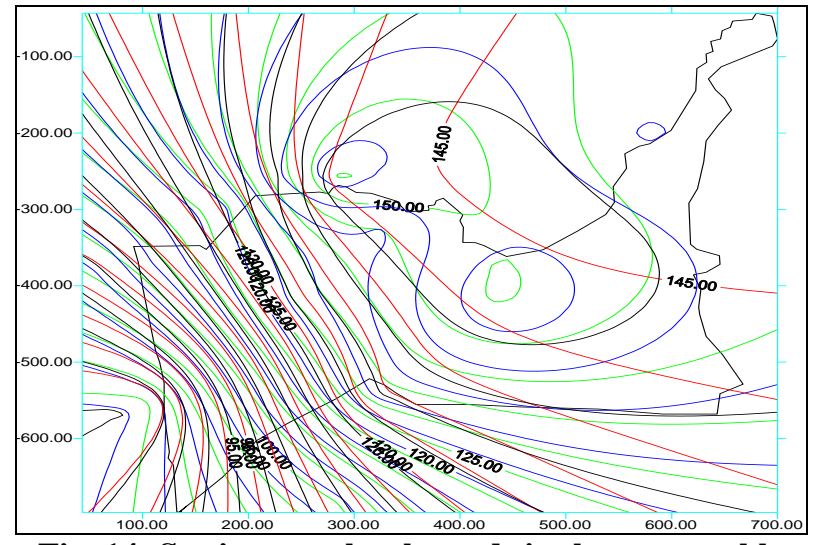

Fig. 14: Static water level trends in the water table aquifer: black:2000, red:2003, blue:2006, green;2008

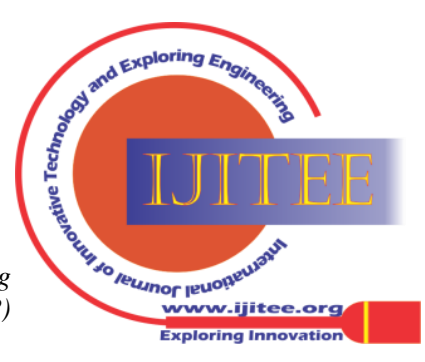




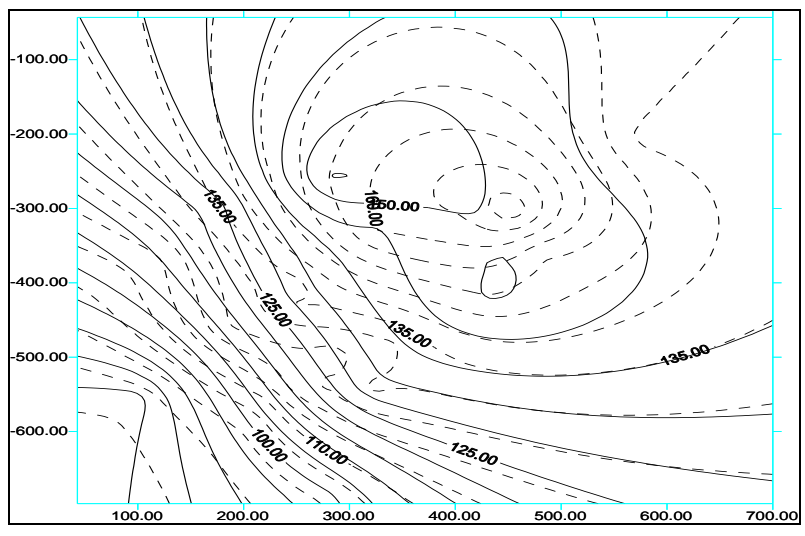

Fig.15 Pre (-) \& post (--) Water Level comparisons in the study area

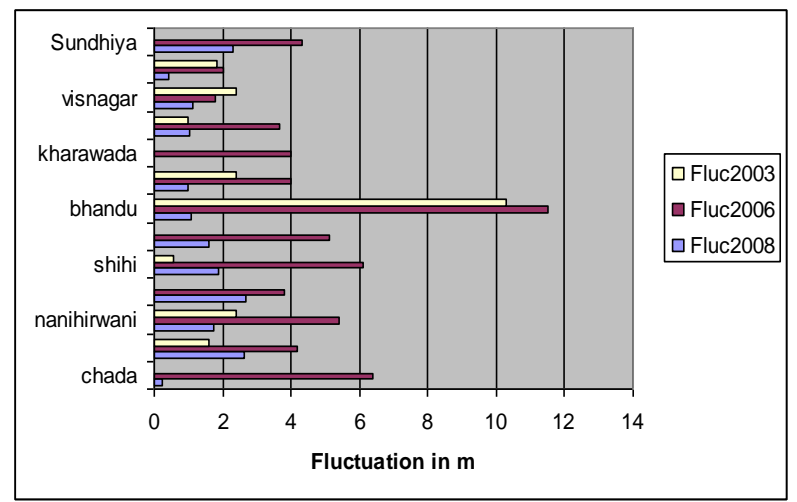

Fig. 16 Water Table fluctuation in various rainfall location

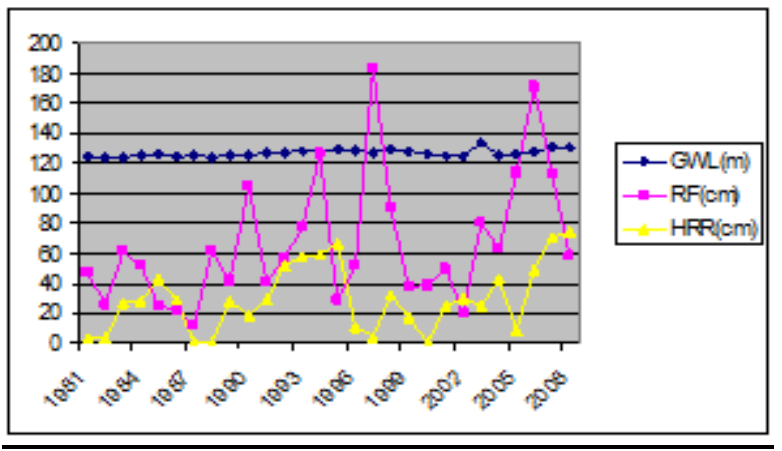

Fig. 17 Relation between GW level (GWL), Rainfall (RF) and Head Regulator Release(HRR) at Visnagar

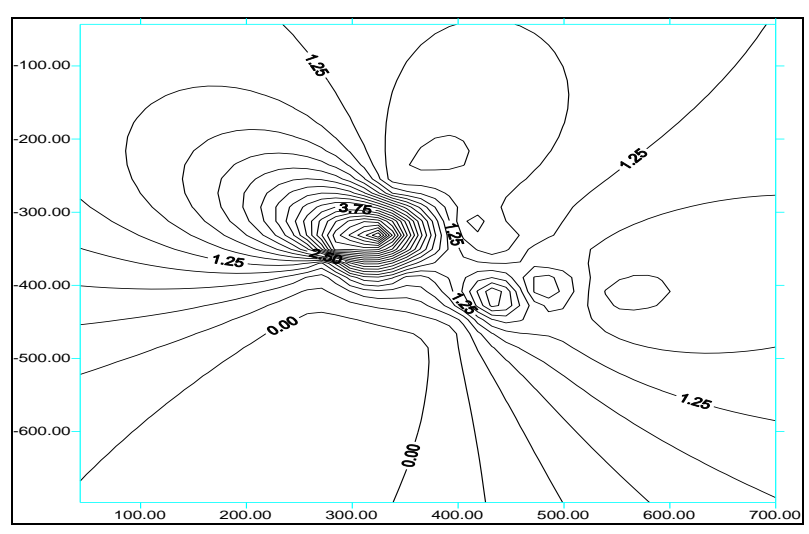

Fig. 18 Surface Recharge pattern in the model area

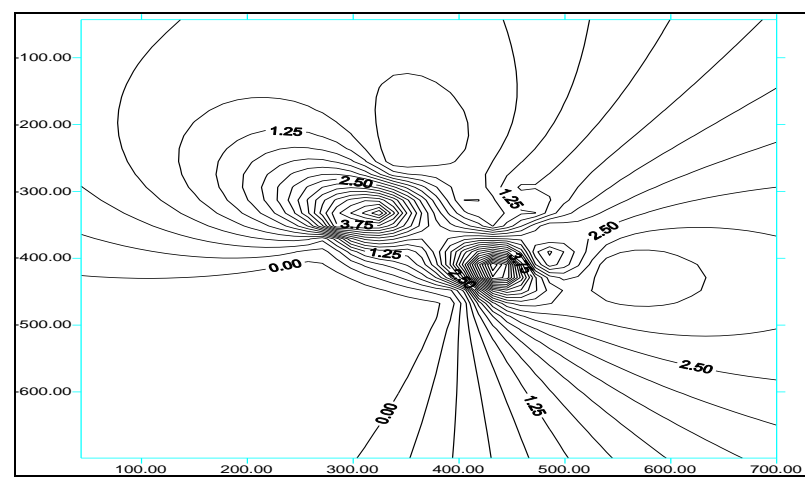

Fig. 19 Groundwater draft pattern in the model area

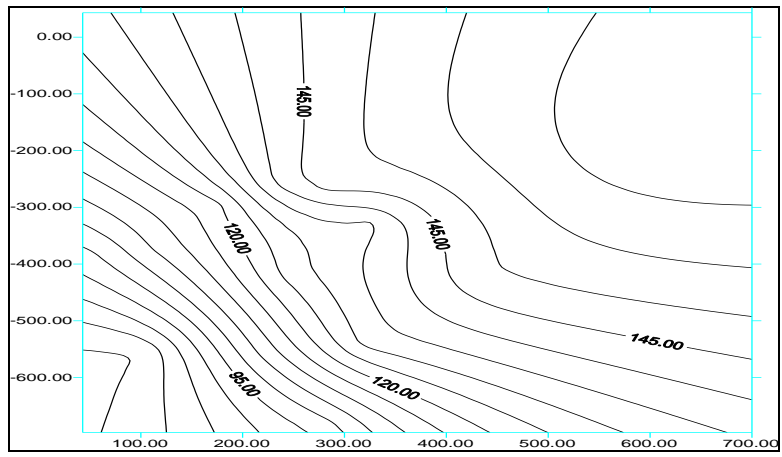

Fig. 20 Initial Water Level input to the calibrated

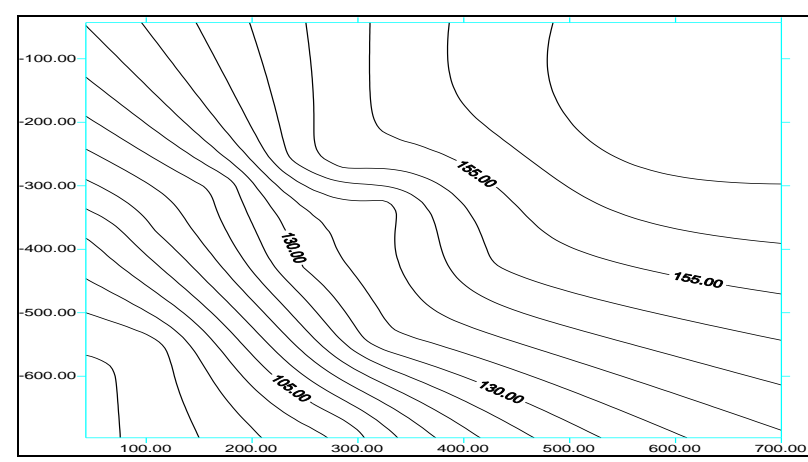

Fig. 21 Obs matching computed results erved water level contours for matching computed

\section{RESULTS AND DISCUSSION}

The conceptualized geometry is processed for calibration under steady state condition with average water level at Dharoi dam in the month of May. This follows with an assumption that water table condition in the month of May is influenced negligibly less due to minimum recharge and discharge options. In steady state condition hydraulic conductivity values need to be calibrated as storage coefficients do not apply. Calibration started with initial parameter values stated in Table 3. The zonal hydraulic conductivity values are changed with trial and error, so that an initial water table condition at the highest boundary condition reaches to an average static water table condition represented by contours in Figure. 14. The calibrated values are shown in Table 3 with reference to spatial distribution of Figure. 22 producing the water table contours of Figure. 23.

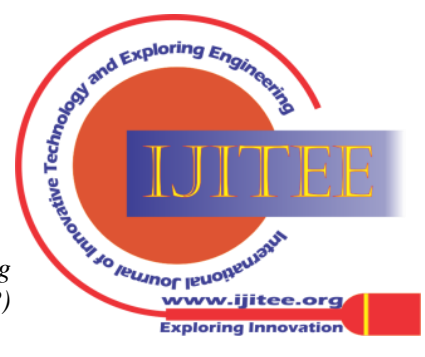


Modelling of Irrigation Return Flow in Unconfined Aquifer of Dharoi Command in Mehsana District of Gujarat, India

Table - 7.1 Calibrated Aquifer Parameters for the Calibration run

\begin{tabular}{|c|c|c|c|c|c|c|c|}
\hline Sr No & $\begin{array}{l}\text { AQUIF } \\
\text { Layer }\end{array}$ & Zone No & $\begin{array}{l}\text { Kxx in } \mathrm{m} \\
\text { per second }\end{array}$ & $\begin{array}{l}\text { Kyy in m } \\
\text { per second }\end{array}$ & $\begin{array}{l}\text { Kzz in m } \\
\text { per second }\end{array}$ & $\begin{array}{l}\text { Porosity in } \\
\%\end{array}$ & Remarks \\
\hline 1 & First & 1 & 0.001 & 0.001 & 0.001 & 0.35 & White \\
\hline 2 & Second & 2 & $1.0 \mathrm{e}-4$ & $1.0 \mathrm{e}-4$ & $1.0 \mathrm{e}-5$ & 0.35 & Blue \\
\hline 3 & Second & 3 & 5.0 e-5 & 5.0 e-5 & 5.0 e- 6 & 0.35 & Green \\
\hline 4 & Second & 4 & 0.0025 & 0.0025 & 0.00025 & 0.35 & Gray \\
\hline 5 & Second & 5 & 0.00015 & 0.00015 & 0.000015 & 0.35 & Red \\
\hline 6 & Second & 6 & 0.00035 & 0.00035 & 0.000035 & 0.35 & Pink \\
\hline
\end{tabular}

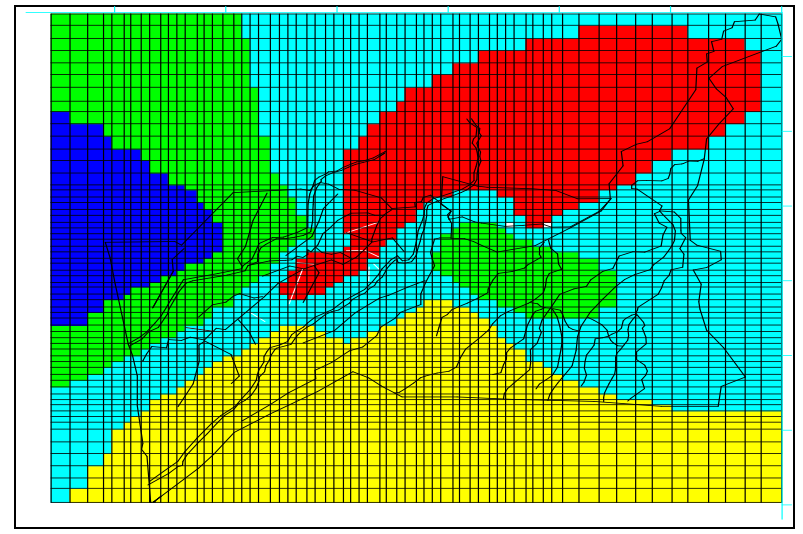

Fig. 22 Hydraulic Conductivity distribution of the second layer of the model area

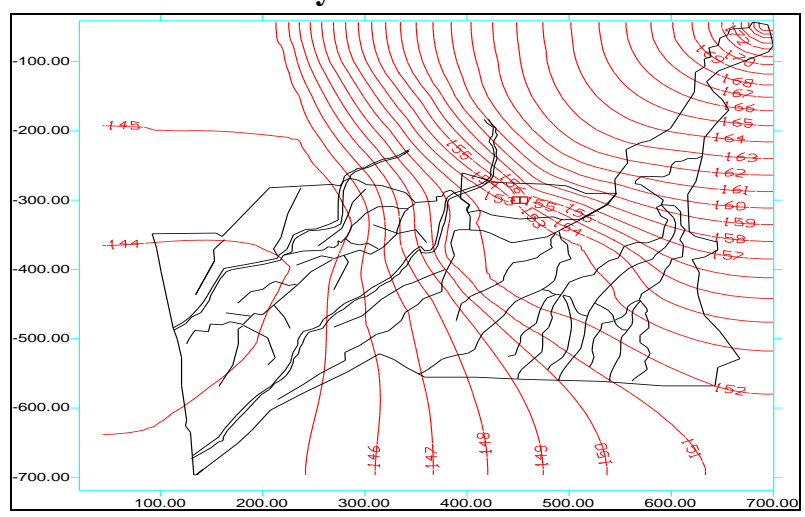

Fig. 23 Calibrated water table contours in the model area under steady state condition

Results are shown pertaining to the second layer of the about $3 \mathrm{~m}$ uniform thickness, philosophically included to have proper field log data representation, otherwise less significant in terms of groundwater development. Top layer is kept under unconfined water table condition, where as the next layer is given the scope of transforming between water table to confined state and vice versa depending upon the fluctuation of the computed water level with respect to the bottom boundary of the top layer. No recharge and discharge options other than a single boundary condition of average May water level in the extreme north-east grid has been allowed. This calibration is based upon matching the observed and computed average gradient of the water table (hydraulic gradient) and nothing to do with matching the point to point values of the observation wells as that could lead to misappropriation in respect of hydrologic condition. Over all gradient of the water table in the area of interest is computed as $0.23 \mathrm{~m}$ per $\mathrm{km}$ in comparison to an observed hydraulic gradient of $0.3 \mathrm{~m}$ per $\mathrm{km}$. Computed water table calibrated model. The first layer is a thin soil cover layer of

contours also follow more or less the surface level contours, which normally happens with hydraulic gradient lines. Therefore the comparison is worth considering the hydraulic conductivity values of table 3 as calibrated.

The behavior of the calibrated model is then tested in the transient condition considering the specific yield distributions in the second layer as shown in Fig. 24(red0.01 , yellow-0.25, green 0.065 and blue 0.105)An average value of Storage coefficient of $1.00 \mathrm{E}-4$ is considered for confined phases. Uniform value of specific yield in the first layer has been considered as 0.01. Recharge and draft options are included based upon a spatial distribution of average village wise values. These are shown in Figures. 25 and 26 for recharge and groundwater draft respectively. An initial water level condition of pre monsoon water table is generated in the transient model.

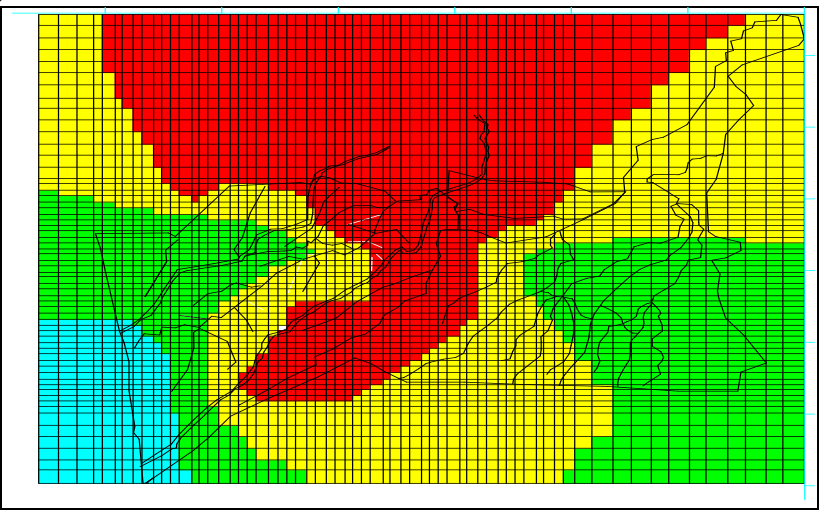

Fig. 24 Specific Yield distributions in the second layer of the model area

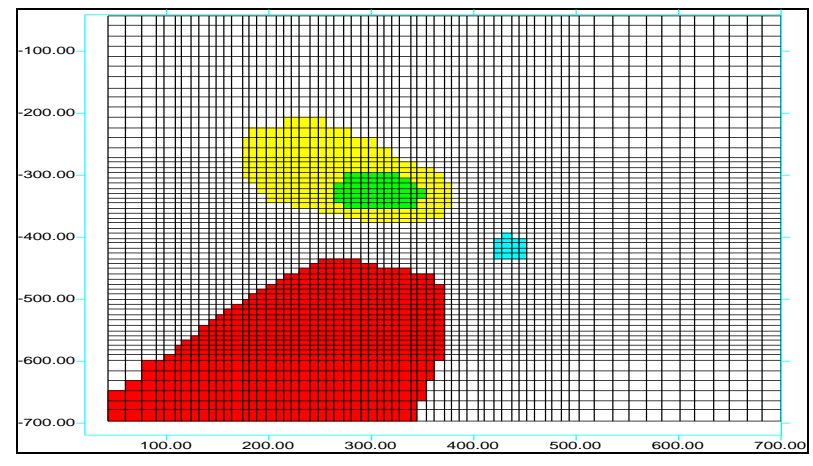

Fig. 25 Spatial Recharge (mm/yr) distributions in the surface area of the model

Published By:

Blue Eyes Intelligence Engineering and Sciences Publication (BEIESP)

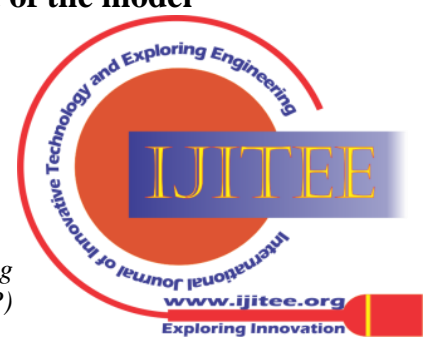




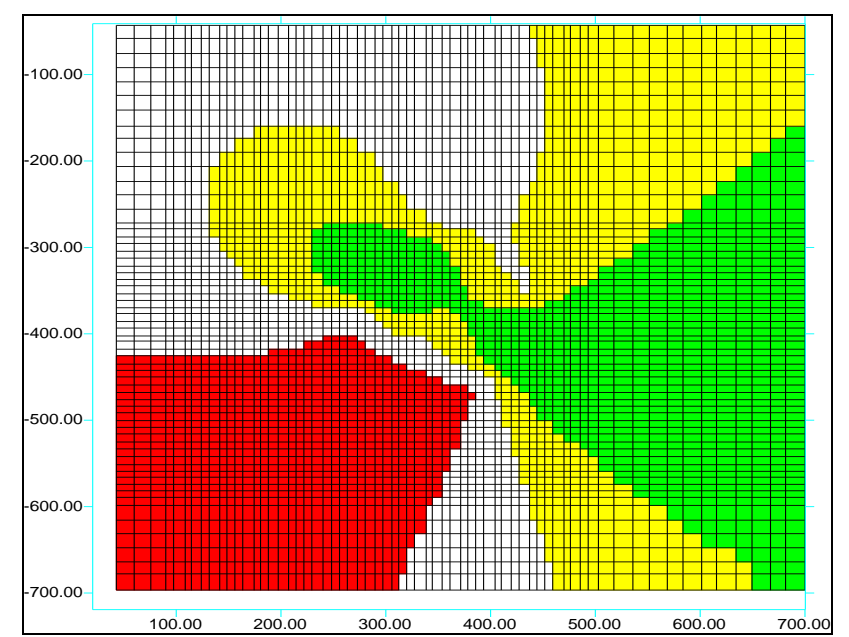

Fig. 26 Spatial groundwater draft $(\mathrm{mm} / \mathrm{yr})$ distribution in the model are

The rivers such as Sabarmati downstream of Dharoi dam and up to Bijapur, Rupen and Pushpawati are activated in the transient run. Base data input for the rivers are shown in Table 4. Conductance value is considered as $0.0001 \mathrm{~m} / \mathrm{sec}$ for all the rivers. The transient run required adjustment of specific yield value of zone 5 from 0.105 to 0.009 for achieving numerical head convergence within $10 \mathrm{~cm}$ and residual error below 0.0001. Although the water table condition in the layer of interest (second layer) was kept in a semi-confined state, however water table condition in the thin soil (first) layer showed dry condition to mean that the computed water levels remained in the proximity of the second layer under unconfined state. Hence storage coefficients input to the model remained unused. Computed water level contours are matched with the observed water level contours in Figure 27. Comparisons of water levels in tselected locations are tabulated in Table 5. Regional groundwater flow direction in the transient run in Figure.28. Overall match between the trends and the point values indicate that the calibrated model transient run can be considered as base case and various options can be studied with this model.

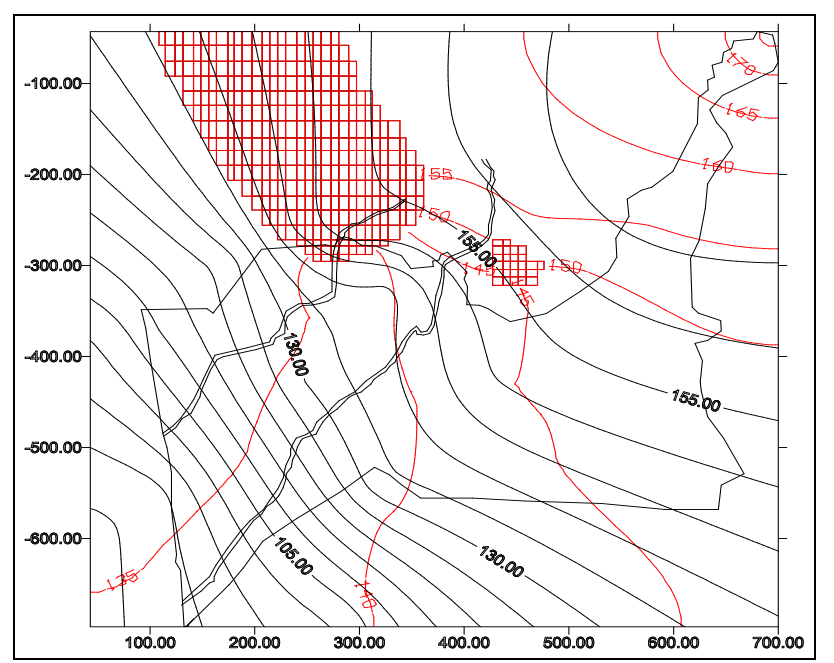

Fig. 27 Comparison of Computed and Observed water level trends
Table - 5 Comparison of Computed and observed water level at selected location

\begin{tabular}{|c|c|c|c|c|}
\hline Sr No & Well Location & $\begin{array}{c}\text { Observed } \\
\text { WL }\end{array}$ & $\begin{array}{c}\text { Computed } \\
\text { WL }\end{array}$ & $\begin{array}{c}\text { Residual } \\
\text { error }\end{array}$ \\
\hline 1 & Sundhia & 163 & 165 & 2.0 \\
\hline 2 & Mandali & 150 & 150 & 0.0 \\
\hline 3 & Nani Hirwani & 159 & 158 & 1.0 \\
\hline 4 & Visnagar & 134 & 130 & 4.0 \\
\hline 5 & Denap & 133 & 130 & 3.0 \\
\hline 6 & Vadnagar & 153 & 150 & 3.0 \\
\hline
\end{tabular}

\section{CONCLUSION}

This study demonstrates that from the use of MODFLOW to know the ground water condition and evaluation of its hydrological response for various land use. From the calibration of MODFLOW to know the hydraulics conductivity distribution of water table under steady state condition, Specific yield distribution, recharge distribution and specific ground water draft distribution. . MODFLOW can be used successfully to simulate the effect of different ground water management practice on ground water regime. Regional flow pattern in the shallow water table aquifer is also suspected to be effected by the flow regimes of Sabarmati River downstream of Dharoi Dam.

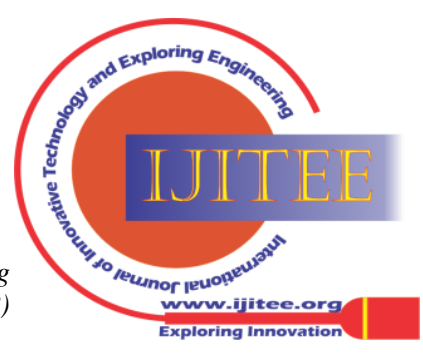


Absence of environmental flow in the river may have affected the groundwater condition. Temporal domain for the modelling exercise is individual monsoon season generally comprised of four months viz. June, July, August and September. Recharge to the study domain is through rainfall in monsoon months and due to irrigation return flow and canal seepage in other months. Also computed the comparisons between observed and computed water level by calibration. By using this model compare the water levels of Sabarmati river ,Rupen river and Pushpavati river and water level of wells ,located at Sundhia, Mandali, Nani Hirvani, Visnagar, Denap, Vadnagar. So, result is found that very less residual error. And know the regional ground water flow direction in the transient recharge. We can predict the ground water level but in this case study the prediction is erroneous due to very small time series available in data.

Visual MODFLOW is very effective to know the present scenario of ground water flow, water level of aquifer, wells also distribution of spatial recharge, specific yield distribution. It gives very close result to the observed value.

\section{ACKNOWLEDGEMENTS}

Authors deeply acknowledge the Geo-referencing support provided by Dr. P. K. Majumdar.

\section{REFERENCES}

1. Dr. Majumdar, P.K Modelling of Coastal Hydrogeology in Krishna Delta of Southern India, Int. J. Society Systems Science, Vol. 2, No. 4, 2010)

2. Dr. Majumdar, P. K., Kumar, S, Singh V. and Jose M. K., "Characterization of Groundwater Flow in Depleting Water Table Areas in Central Punjab", Proc XII World Water Congress of IWRA, 22-25 November, 2005, New Delhi.

3. Groundwater flow modelling of multi-aquifer systems for regional resources evaluation: the Gdansk hydrogeological system, Poland Beata Jaworska-Szulc, Received: 14 November 2007 / Accepted: 21 April 2009 Published online: 30 May 2009 * Springer-Verlag 2009Kai-Yuan Ke (2014)

4. Application of an integrated surface water-groundwater model to multi-aquifers modeling in Choushui River 11.Hydroligical process, January 2014, Pages 1409-1421

5. Kavalannekar, N.B., S.C. Sharma, and Rushton K.R. (1992), Overexploitation of an alluvial aquifer in Gujarat, India, J. Hydrological Sciences, 37(4), 329-346.alluvial fTaiwan,

6. U. S. Geological Survey. Modelling groundwater flow with MODFLOW and related programs USGS Fact Sheet, FS-121-97. 1997 Aug. USA: United States Geological Survey.

7. Kumar CP. Numerical Modelling of Ground Water Flow using MODFLOW. Indian Journal of Science. 2013; 2(4): 86-92p.

\section{AUTHORS PROFILE}

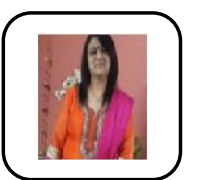

Hema R. Parmar, Education: M.E. (WRE) From L.D Engineering, Gujarat University, PHD Persuing. Publications:

1.Setting of co-relation in Hydro-geology in Sabarmati Basin,Gujarat,India.Hema R. Parmar, Dr. N.D.Shah, Dr.P.K.Majumdar,Paper present and Published in ,The Third Intl. Conf. On Advances in Civil, Structural and Mechanical Engineering - ACSM 2015 ,at Bangkok,Institute of Research Engineers and Doctors, USA .All rights reserved.ISBN: 978-1-63248-083-5 doi: 10.15224/ 978-1-63248-083-5-65. 2. Establishe co-relation of Hydro Gyological by rockworks in Command Area. Hema R. Parmar2, Dr.N.D.Shah2,Dr. P.K.Majumdar3International Journal of Scientific Research ,Volume 8, Issue 4,April 2017. ISSN 22295518(UGC Journal)

3. Model Application for salinity in Command Area.Hema R. Parmar 1, Dr.N.D.Shah2,Dr. P.K.Majumdar., IOSR Journal of Mechanical and Civil Engineering (IOSR-JMCE) e-ISSN: 2278-1684,p-ISSN: 2320-334X,

Volume 14, Issue 3 Ver. I (May. - June. 2017), PP 01-11 www.iosrjournals.org(UGC Journal)

4. A Study Of Ground Water Modeling For Shallow Aquifer , In Gandhinagar District, Gujarat ,BY

1. Hema R. Parmar 2. Dr.N.D.Shah, 3. Dr. P.K.Majumdar

International Journal of Technical Innovation in Modern Engineering \& Science (IJTIMES) Impact Factor: 3.45 (SJIF-2015), e-ISSN: 2455-2584

Volume 3, Issue 06, June-2017(UGC Journal)

5.Study of Ground water condition in multi Aquifer in Dharoi Command Area By GIS and Rockworks,

1Hema R. Parmar, 2Dr.N.D.Shah, 3Dr. P.K.Majumdar

International Journal of Scientific Research and Review,Volume 7, Issue 3 , 2018,ISSN NO: 2279-543X(UGC Journal)

6. Model Application to Solve Salinity Problems in Study Area of Sabarmati River Basin in Gujarat, India.

1. Hema R. Parmar 2. Dr.N.D.Shah, 3. Dr. P.K.Majumdar

Paper present and Published in,International conference ,Hydro-2017 International, L.D. College of Engineering Ahmedabad, India

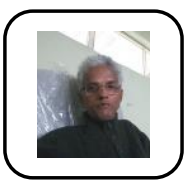

Pradeep Majumdar, Education: $\mathrm{PhD}$, Indian Institute of Science, Bangalore, India .

Books: More than 20 books.

Projects

1.From 12/1998 to 07/2003, Study of Artificial Recharge in Maharashtra. , World Bank Project encompassing study of 3 specific sites in Ozhar, Bamnod and Baramati in Maharashtra 2. $12 / 1998$ to $07 / 2003$, Study of Artificial Recharge in Maharashtra. World Bank Project encompassing study of 3 specific sites in Ozhar, Bamnod and Baramati in Maharahtra.

3.From 12/1998 to 07/2003, Fresh water Saline water interrelationships in the multi- aquifer system of Krishna Delta in coastal Andhra Pradesh. World Bank Project for developing numerical model in Krishna Delta in Andhra Pradesh

4.From 07/2003 to 12/2004, Groundwater modelling in central Punjab under Information Technology for Sustainable Agriculture in Punjab (ITSAP), UNDP and TIFAC, DST sponcered Project to understand depleting water table conditions

5.From 01/1997 to 04/1997, Conceptual Design for Water supply systems Package 1 Villages of Ron and Nargund Taluks in Dharwad. , Neetherland Assisted Project to provide domestic water to water scarce villages

6.From 01/2004 to 04/2004, Environmental Impact Assessment of a secured Landfill in Ankaleshwar, Gujarat, Concultancy based project eased by Bharuch Enviro Infrastructure Ltd., Ankaleshwar and National Productivity Council, New Delhi to assess the risk and the uncertainties involved in leachate migration to groundwater

7.From 07/2007 to 06/2008, Seepage estimation in Jaswantsagar project, Jodhpur, Govt of Rajasthan, India forwarded project to analyse the reasons for increase in seepage flow.

Journal Articles

1.P. K. Majumdar, N. C. Ghosh \& B. Chakravorty, Analysis of Arsenic Contaminated Groundwater Domain in Nadia District of West Bengal, Journal of Hydrological Sciences, 47S, August 2002, S55-S66.

2.P. K. Majumdar, M. Sekhar, K. Sridharan \& G. C. Mishra, Numerical simulation of groundwater flow with gradually increasing heterogeneity due to clogging, Journal of Irrigation and Drainage Engineering, Vol. 134, No. 3, May/June 2008, pp. 400-404

3.P. K. Majumdar, G. C. Mishra, M. Sekhar \& K. Sridharan, Coupled Analytical Solutions for Forced Well Recharge in Confined Aquifers, ASCE J. Hydrological Engineering , 14(12), 2009, 1351-1358.4.P. K. Majumdar, S. Ram \& P. R. Rao, Artificial Recharge in multi aquifers of a mountainous watershed, ASCE J. Hydrological Engineering, 14(3), 2009, 215-222

5.G. C. Mishra \& P. K. Majumdar, Unsteady Solution for Well Recharge in A Low Diffusive Aquifer, J. Irrigation and drainage, ASCE, Vol. 136, No. 12, December, 2010

6.P. K. Majumdar, Modeling of Coastal Hydrogeology in Krishna Delta of Southern India, Int. J. Society Systems Science, Vol. 2, No. 4, 2010, 351 374

7.P. K. Majumdar, Sustainability of Societal Water Management Practices, Int. J. Society Systems Science, Vol. 5, No.2, 2013, 113-135.

8.P. K. Majumdar, K. Sridharan,G. C. Mishra, M. Sekhar, Unsteady Equation for Free Recharge in a Confined Aquifer, Journal of Geology and Mining Research Vol. 5, No. 5, May 2013, 114-123.

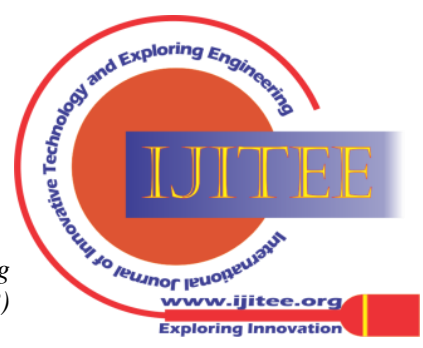


9.P. K. Majumdar and S Ram, Source and Impact assessment of artificial recharge in water scarce interfaced multi-formation, International Journal of Advanced Research, Volume 1, Issue 4, 2013, 83-91

9.P. K. Majumdar, New Dimensions in Reservoir Sedimentation, Lakes and Reservoirs: Research and Management 2015 20: 1-12

10.N. Yoganarsimhan \& P. K. Majumdar "Graphic Aided Design of Minor Irrigation Scheme in Saurashtra Region of Gujarat"; Navnirman, JulyDecember 1990 .

11.P. K. Majumdar, P. V. Seethapathy \& B. K. Purandare, "Groundwater Pollution in Palar River Basin, Tamilnadu"; Journal of AHI,Vol.IX, No.3\&4,1996 and communication paper in Golden jubilee session of Central Board of Irrigation and Power, New Delhi, September 1995.

12.P. K. Majumdar \& P. V. Seethapathy, "State of Art for Groundwater Quality Modelling", published in the Journal of Indian Society of Hydraulics, September-October 1996, Vol 2 No 2.

15.P. K. Majumdar, Improved Conceptual Development for water-logging and salinity in Irrigation Command, Under review in Int Journal for Society System Science publication.

16.P. K. Majumdar, Multi-Aquifer Parameterization with well loss in Vertical Flows, Journal of Water Resource and Hydraulic Engineering, Jan. 2015, Vol. 4, Iss. 1, PP. 9-22

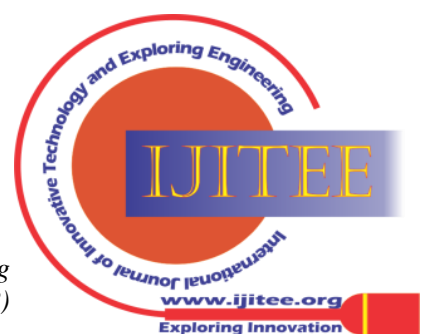

